\title{
PERANCANGAN IDENTITAS VISUAL BERBASIS RELIGI DAN BUDAYA PESISIR DI KOTA DEMAK
}

\author{
Agus Rochani ${ }^{1}$ \\ Prodi Perencanaan Wilayah dan Kota Fakultas Teknik \\ Universitas Islam Sultan Agung Semarang \\ Email: agusplanoo@gmail.com
}

\begin{abstract}
ABSTRACK
The identity of the city is a form of visual that represents the mental image of the average people. Demak as a city on the north coast of Java Island has much historical value in terms of the spread of Islam. The collaboration between the two aspects is very interesting to expres in the form of a visual identity of the city. This study aims to develop a visual identity design based on the religious values and coastal culture in Demak. The research is formulating qualitatively, which is built from natural basic elements, which depart from data, utilizing existing theories as explanatory material and ending with an identity concept. The design of identity adopts Islamic architectural forms and values at the Great Mosque of Demak, which is collaborated with city characters coast, represented by the shape of sea waves, Islamic ornaments and traditional Javanese Demak Djung boats.
\end{abstract}

Key word: regional image, visual identity, mass composition.

\begin{abstract}
ABSTRAK
Identitas visual kota merupakan wujud visual yang mewakili gambaran mental rata-rata masyarakatnya. Kota Demak sebagai kota yang berada ada di pesisir utara Pulau Jawa memiliki nilai historis yang kuat dalam hal penyebaran Agama Islam. Kolaborasi kedua aspek tersebut sangat menarik dituangkan dalam bentuk indentitas visual kota. Penelitian ini bertujuan menyusun rancangan indentitas visual yang dikembangkan berdasarkan nilai nilai religi dan budaya pesisir di Kota Demak. Penelitian dirumuskan secara kualitatif, yang dibangun dari elemen elemen dasar alamiah, yang berangkat dari data, memanfaatkan teori yang ada sebagai bahan penjelas dan berakhir dengan sebuah konsep identitas. Perancangan identitas mengadopsi bentuk dan nilai arsitektural Islam di Masjid Agung Demak, yang dikolaborasi dengan karakter kota pesisir diwakili oleh bentuk ombak air laut, ornamen Islam dan kapal tradisional Demak Djung Jawa.
\end{abstract}

Kata kunci: citra kawasan, identitas visual, gubahan masa. 
Jurnal Planologi Vol. 18 No. 1, April 2021

Available: http://jurnal.unissula.ac.id/index.php/psa

\section{LATAR BELAKANG PENELITIAN}

Kota Demak merupakan salah satu kota yang berada ada di pesisir utara Pulau Jawa, dimana kehidupan masyarakat sangat terpengaruh dengan budaya masyarakat pesisir. Kota Demak juga merupakan salah satu kota tua dengan sejarahnya yang cukup panjang, sehingga menjadi salah satu kota yang berpengaruh di Pulau Jawa (Marwoto. Wulandari, 2014). Pada jaman dulu, Kota Demak merupakan salah satu pusat kerajaan di Pulau Jawa yaitu Kesultanan Demak atau Kerajaan Demak yang merupakan Kerajaan Islam pertama. Jumlah penduduk Kota Demak pada tahun 2019 sebanyak 62.682 jiwa. Dengan luas wilayah mencapai 40,61 km², maka angka kepadatan bruto penduduk mencapai $1.543 \mathrm{jiwa} / \mathrm{km}^{2}$.

Kota Demak berperan sebagai pusat pemerintahan Kabupaten Demak. Peran ini menjadikan kawasan binaan di Kota Demak terus mengalami perkembangan seiring meningkatnya jumlah penduduk. Berbagai fungsi pelayanan berskala kabupaten berkembang di kawasan ini, baik berupa pusat pemerintahan, pusat perdagangan bisnis usaha, pusat pariwisata dan lain sebagainya. Sebagai salah satu pusat pariwisata nasional, Kota Demak memiliki ikon cagar budaya berupa kawasan masjid Agung Demak, Kawasan masjid Kadilangu serta berbagai kawasan pendukung pariwisata lainnya.

Kota Demak terletak pada jalur jalur transportasi nasional. Jaringan jalan arteri primer di Kota Demak berperan sebagai jalur penghubung utama antara kota ordo satu Semarang dengan kota ordo satu Surabaya. Jalur ini berfungsi sebagai jalur pengumpul atas arus lalu lintas kolektor menuju jalan bebas hambatan/ekspres. Dengan fungsi ini maka karakter jalur arteri akan memiliki kecepatan tinggi dan arus pergerakan lokal akan dibatasi untuk menjamin kecepatan yang diharapkan (60-80 km/jam).

Jalur arteri Kota Demak berperan penting dalam mendorong pertumbuhan dan perkembangan ekonomi wilayah. Berbagai jenis moda transportasi darat termasuk kendaraan alat berat melewati jalur ini. Fenomena in menjadikan kawasan sepanjang jalur arteri memiliki nilai strategi yang tinggi bagi perkembangan ekonomi dan sosial. Penataan ruang pada koridor jalan arteri sangat menentukan karakter dan citra kawasan. Keberadaan elemen penanda sangatlah penting untuk membentuk jatidiri dan pengembangan citra diri bagi Kota Demak. Salah satu lokasi strategis yang memiliki potensi bagi pengembangan citra visual adalah di perempatan fly over Botorejo. Kawasan ini terletak di sisi selatan kota, yang menghubungkan antara jalan lingkar kota (arteri pantura) dengan jalan Sunan Kalijaga serta jalan Demak-Purwodadi. Taman terletak di jalur melingkar, dengan fungsi utama sebagai pemecah arus transportasi serta sebagai penghantar elevasi (ram) jalan. 
Jurnal Planologi Vol. 18 No. 1, April 2021 Available: http://jurnal.unissula.ac.id/index.php/psa

Mempertimbangkan berbagai potensi lokasi di atas, maka dilakukan penelitian yang bertujuan menyusun rancangan desain indentitas visual berdasarkan nilai nilai identitas religi dan budaya pesisir di Kota Demak. Hasil perancangan ini diharapkan dapat menjadi tetenger bagi kota serta membaca citra diri bagi sistem penanda kota di masa yang akan datang.

\section{METODOLOGI PENELITIAN}

Pengembangan identitas visual pada suatu entitas perlu dilakukan berdasar nilai nilai budaya yang dapat mewakili karakter jatidiri. Salamah \& Yananda, (2019) menegaskan bahwa identitas kota harus memenuhi beberapa unsur penting diantaranya artefak fisik yang menjadi ciri khas suatu kota, sejarah masa lalu, masa kini, preskripsi masa yang akan datang, serta memori kolektif yang dimiliki mayoritas penduduk kota. Identitas kota yang terus diperjuangkan akan dapat menggambarkan kolektivitas identitas yang dirangkum dalam suatu simbol. Proses ini memerlukan pencarian yang mendalam terhadap benang merah suatu kota, yang dibangun dari apa yang benar-benar sudah dimilikinya, potensi dan kendala internal serta peluang hambatan eksternal, yang pada akhirnya dapat menjadi identitas dan kekuatan kota (Siraphatthada \& Thitivesa, 2020).

Menuju proses di atas, penelitian ini dirumuskan secara kualitatif yang dibangun dari elemen elemen dasar alamiah, yang berangkat dari data, memanfaatkan teori yang ada sebagai bahan penjelas dan berakhir dengan sebuah konsep identitas (Sugiyono, 2005). Sebagai penelitian deduktif kualitatif, penelitian ini akan memanfaatkan sumber teori yang bisa diverifikasi sebagai bekal dalam melakukan penelusuran nilai nilai lokal. Berdasarkan temuan karakter dasar di lapangan, maka dikembangkan bentuk bentuk dasar dan pengembangan secara pragmatic design. Perancangan ini menempatkan perancangan arsitektur dengan cara trial and error yang diawali dengan dua dimensional, dilanjut ke bentuk sketsa tiga dimensional hingga bentuk visual development design. Dari proses ini akan dihasilkan alternatif desain, yang dalam perkembangannya akan dituangkan dalam bentuk aspek/ kriteria/prinsip tertentu seperti geometrik obyek, sistem skala dan proporsi hingga tata aturan massa bangunan (canonic design)(Lawson, 1980). Sebagai perancangan elemen kota, maka pendekatan ini menuntut kepatuhan terhadap berbagai Norma, Standar, Prosedur dan Kriteria (NSPK) yang berlaku di Indonesia. 
Jurnal Planologi Vol. 18 No. 1, April 2021

Available: http://jurnal.unissula.ac.id/index.php/psa

\section{HASIL DAN PEMBAHASAN}

Pengembangan identitas visual kota ditujukan untuk memberikan citra atas kota dimaksud. Citra kota dapat didefinisikan sebagi gambaran mental dari sebuah kota sesuai dengan rata-rata pendangan masyarakatnya (Zahn Markus; 1999). Kevin Lynch mempertegas dalam buku Citra Kota, bahwa terdapat tiga komponen yang sangat mempengaruhi pencitraan orang terhadap suatu kawasan (Lynch, 1984) adalah:

1. Identitas; bahwa citra kota dibentuk dari identitas yang dapat dibaca, sehingga orang akan mudah memahami gambaran suatu perkotaan melalui identifikasi objek-objek yang ada, serta penilaian perbedaan antara objek yang ada di kota tersebut.

2. Struktur; bahwa citra kota dibentuk dari hubungan objek-objek, hubungan objeksubjek, pola yang dapat dilihat hingga membentuk struktur yang lengkap pada suatu kota.

3. Makna; bahwa suatu kota akan memiliki potensi untuk dibayangkan pada waktu dan tempat yang lain. Makna dibentuk dari arti objek, arti subjek-objek, rasa yang dapat dialami terhadap berbagai dimensi simbolik, fungsional, emosional, historik, budaya, politik yang ada di kota tersebut.

Mencermati definisi di atas, maka citra suatu kota akan terbentuk dari adanya suatu karakter yang khas, yang disusun oleh berbagai elemen elemen hingga menjadi sebuah struktur yang kompak dan dapat dibayangkan oleh para pengguna ruang kota. Identitas visual pada perancangan arsitektur dibentuk dari aspek aspek monumental sebagai ciri khas massa bangunan yang memiliki karakter atau jatidiri kuat, hingga bisa dibedakan dengan massa bangunan lain disekitarnya. Monumentalitas bagi Permana (1995) dibentuk dari pertimbangan hal-hal yang terukur dan juga tidak terukur seperti: cita rasa, presepsi manusia, dan daya cipta sehingga diyakini dapat membentuk sendi kehidupan manusia atau disebut dengan budaya. Beberapa gagasan terbaru terkait monumentalitas antara lain:

a. Monumentalitas yang hidup lebih lama dan dapat mengakomodasi dari selang periode yang ada disebut sebagai human landmark. Hal ini menjadikan ada kedekatan antara masa kini dengan masa lalu yang ditampilkan dalam bentuk monumentalitas massa bangunan.

b. Monumentalitas menjadi kebutuhan budaya dengan tahapan paling tinggi dari eksistensi daya nalar manusia disebut sebagai ekspresi. Termasuk dalam hal ini adalahpuncak puncak peradaban (trigger) yang bisa dijadikan tetenger terjadinya suatu peristiwa. 
c. Monumen merupakan tahapan kebutuhan akomodasi fungsi yang sudah terpenuhi dengan kebutuhan wilayah/urban yang melebihi dari fungsional tertentu.

d. Menurut Redman dalam Belia (2010) monumen adalah sekumpulan dari beberapa aturan symbol. Namun dalam teori komunitas dengan bentuk kontribusi terhadap pembentukan fisik kawasan menjabarkan terkait pentingnya konsep organisasi atau komunitas.

\section{Analisis dan Rancangan Identitas Visual}

Perancangan identitas visual Kota Demak dikembangkan pada area seluas $8.670 \mathrm{~m}^{2}$. Secara administrasi lokasi penelitian berada di Kelurahan Botorejo, Kecamatan Wonosalam, Kabupaten Demak. Lokasi perencanaan merupakan taman sirkulasi di samping jalan arteri primer dan penghubung ke jalan Sultan Kalijaga dan Jalan Demak-Purwodadi. Karakter lahan berupa taman sirkulasi dengan elemen vegetasi berupa perkebunan jambu dan tanaman penutup lahan (grass land cover) berupa rumput. Lokasi tersebut berdekatan dengan permukiman penduduk.

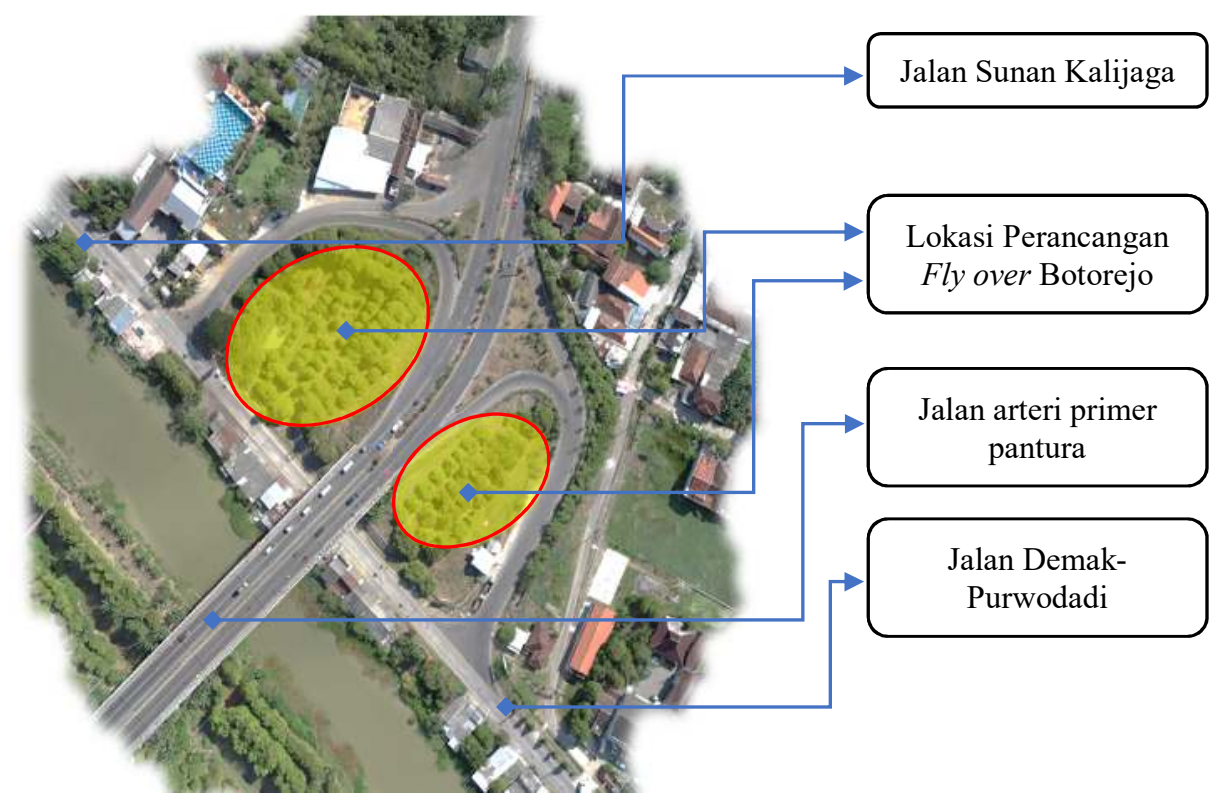

Gambar 1. Tapak Lokasi Penelitian

Lokasi taman fly over Botorejo terletak disamping jalan lingkar Kota Demak-Kudus. Lokasi ini memiliki aksesibilitas yang baik, mudah dijangkau dari berbagia arah. Keberadaan jalan arteri sebagai jalur cepat juga memberikan kemudahan dalam hal pencapaian dari luar kota. Peraturan zonasi pada lokasi penelitian merupakan Ruang 
Terbuka Hijau (RTH) taman kota. Hal ini dipertegas dalam dokumen Rencana Detail Tata Ruang Kota (RDTR) Kota Demak. Berbagai infrastruktur pendukung seperti jaringan listrik dan jalur telekomunikasi sudah berkembang di kawasan ini. Kondis site eksisting berupa lahan kosong dan kebun jambu dengan dasar tapak yang berkontur datar dan memiliki elevasi naik dari jalan utama. Posisi lokasi merupakan jalur masuk dari arah selatan kota, yang menghubungkan kawasan masjid Kadilangu dengan Kota Demak. Lebih lanjut kawasan ini berkembang sebagai pusat kegiatan ekonomi masyarakat kota.

\subsection{Konsep Perancangan Site}

Berdasarkan hasil analisis terhadap potensi lokasi dan tema perancangan, maka disusunlah beberapa kriteria yang akan digunakan dalam perancangan untuk mendapatkan hasil yang optimal. Penjabaran kriteria-kriteria objek perancangan adalah sebagai berikut :

a. Konsep Zoning (Peletakan Massa)

Konsep pembagian zonasi didasarkan pada jenis kegiatan serta analisa lainnya yang menjadi pertimbangan penetapan masa bangunan.

b. Konsep The View (Sudut Pandang) Merupakan pandangan yang diamati dari sudut pandang tertentu dan pandangan tersebut merupakan batas ruang visual yang memiliki daya tarik dan membangkitkan perasaan bebas.

c. Konsep The Vista (Pemandangan)

Vista berhubungan dengan view yang berarti pandangan sejauh yang dapat tertangkap oleh mata manusia. View hanya dapat dibatasi oleh sesuatu yang menghalangi.

d. Konsep The Axis (Tapak/sumbu)

Axis merupakan elemen rencana linier yang menghubungkan dua titik atau lebih yang memiliki keterbatasan yang merupakan salah satu ciri yang dominan pada lansekap.

e. Konsep The Symmetrical Plan (Rencana Simetris)

Elemen dari suatu rencana simetris sama dan berada dalam keseimbangan sekitar titik pusat atau sisi yang berlawanan dari garis sumbu, dimana titik sentral dalam hal ini menjadi objek.

f. Konsep The Asymmetrical Plan (Rencana asimetri). 
Perencanaan asimetri merupakan kedekatan hubungan dengan alam yang harmonis, menyajikan kualitas lanskap yang tampak alami, sirkulasi lebih bebas dan pemandangan yang bervariasi.

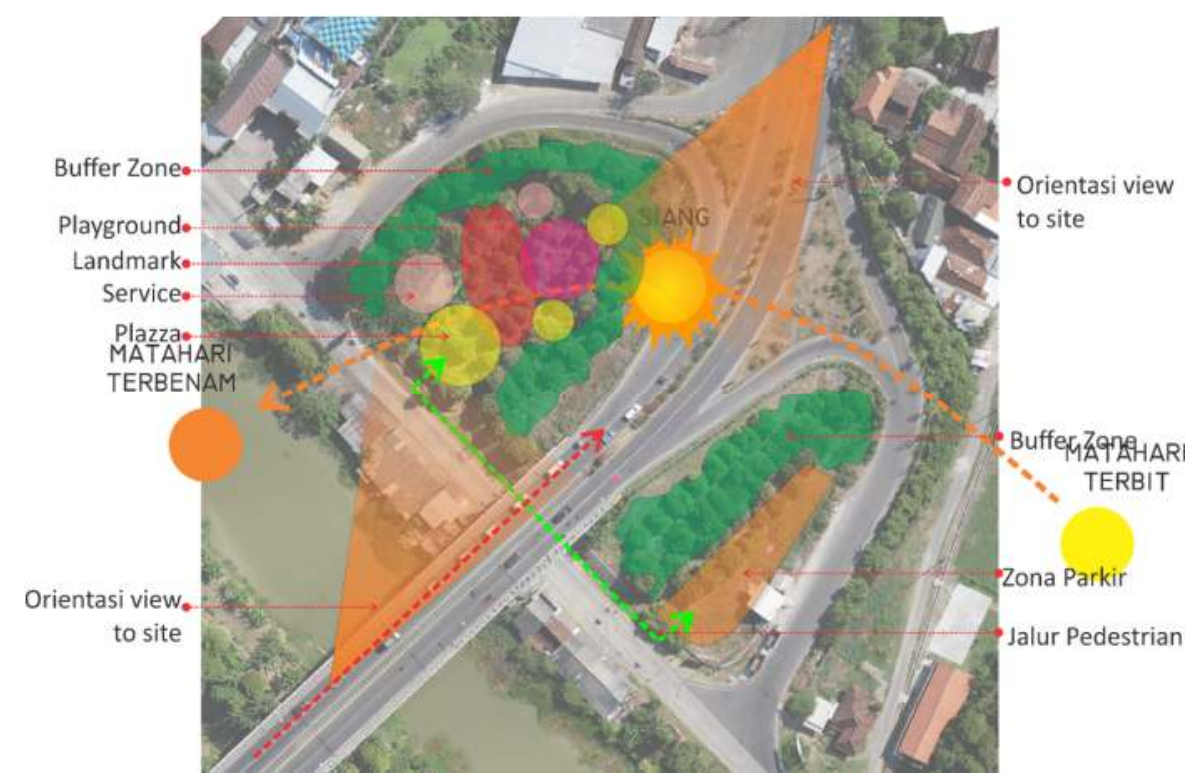

Gambar 2. Analisis site dan konsep peletakan masa

\subsection{Pengembangan Konsep Religi dan Budaya Pesisir}

Penggalian konsep religi merupakan upaya memahami karakter Kabupaten Demak sebagai entitas agama islam. Pada kawasan ini terdapat Masjid Agung Demak sebagai salah satu masjid tertua di Indonesia. Masjid yang berada di Kampung Kauman ini dipercaya pernah menjadi tempat berkumpulnya para Waliyulloh (Walisongo) dalam rangka mensyiarkan agama Islam di tanah Jawa. Pendiri masjid ini diperkirakan adalah Raja Demak pertama yang bernama Raden Patah sekitar abad ke-15 Masehi. 


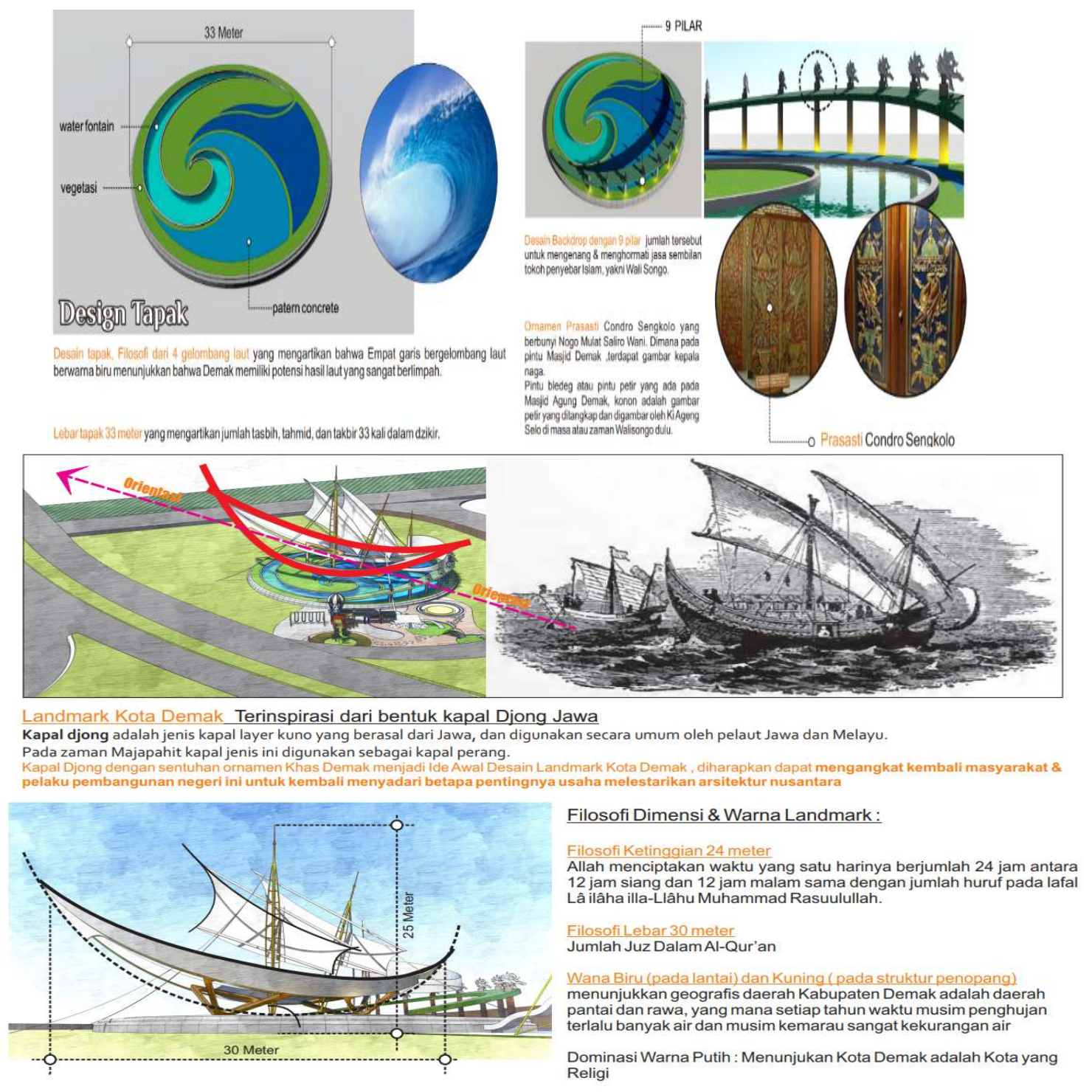

Gambar 3. Pengembangan Konsep Religi Islam dan Budaya Pesisir

Konsep arsitektural yang khas pada masjid Agung Demak adalah struktur ruang yang terdiri dari bangunan-bangunan induk dan serambi. Bangunan induk memiliki empat tiang utama (saka guru), yang salah satunya berasal dari serpihan kayu (saka tatal). Bangunan induk merupakan bangunan tertutup dengan fungsi utama sebagai tempat sholat. Sedangkan bangunan serambi merupakan bangunan terbuka dengan berbentuk atap limas yang ditopang delapan tiang Saka Majapahit. Atap masjid yang tersusun dalam tiga tingkatan yang mengandung makna Iman, Islam dan Ikhsan. Pintu utama masjid dinamakan sebagai "Lawang Bledeg" terdapat tanda candra sengkala, yang dapat dibaca sebagai "Naga Mulat Salira Wani”, yang berarti pendirian masjid pada tahun 1.388 Saka atau tahun 887 Hijriyah. 
Perancangan identitas visual kota mengadopsi bentuk dan nilai arsitektural diatas, yang dikolaborasi dengan karakter Kota Demak sebagai kota pesisir. Konsep gubahan masa mengadopsi beberapa bentuk yang familiar dijumpai di Kota Demak, antara lain bentuk dari bentuk ombak air laut, budaya Islami di Demak dan bentuk kapal tradisional Demak (Djung Jawa). Kedua aspek ini dituangkan dalam bentuk komposisi desain tapak dan desain ornamen sebagaimana dalam gambar di atas.

\subsection{Perancangan Identitas Visual}

Berdasarkan penggalian terhadap konsep religi dan budaya pesisir di atas, maka dilakukan perancangan terhadap lokasi site. Area perancangan meliputi site di sisi utara seluas $5.470 \mathrm{~m}^{2}$ dan di sisi selatan seluas $3.200 \mathrm{~m}^{2}$. Zonasi tapak pada sisi utara digunakan sebagai ruang ataksi utama berupa landmark dan area taman/Ruang Terbuka Hijau. Sedangkan pada sisi selatan digunakan sebagai ruang penunjang berupa lahan parkir dan pertamanan. Pada area ditetapkan buffer kanan-kiri sepanjang 100 meter akan digunakan untuk perluasan kantong parkir jika pada lokasi selatan mengalami overload.

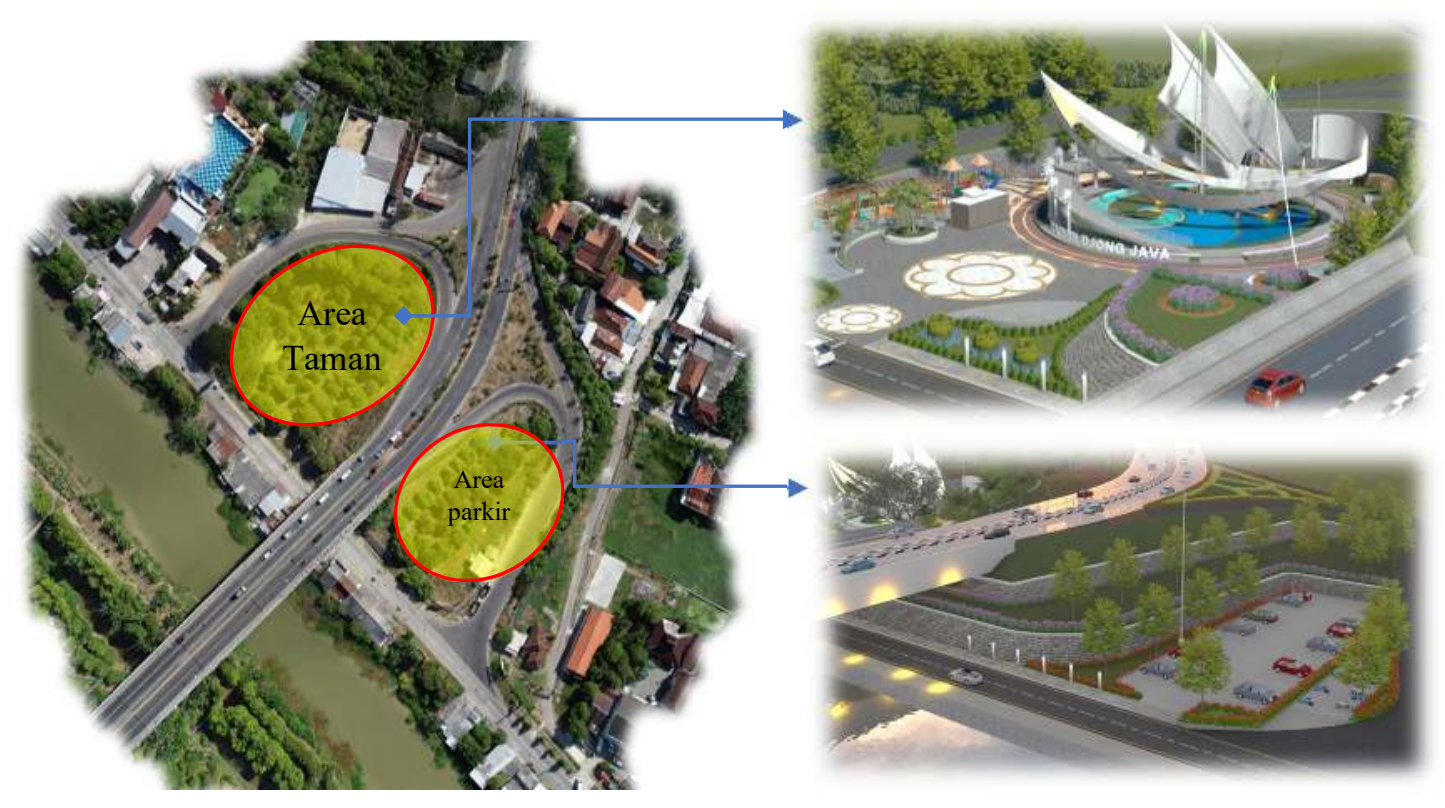

Gambar 4. Pembagian Zonasi Site 

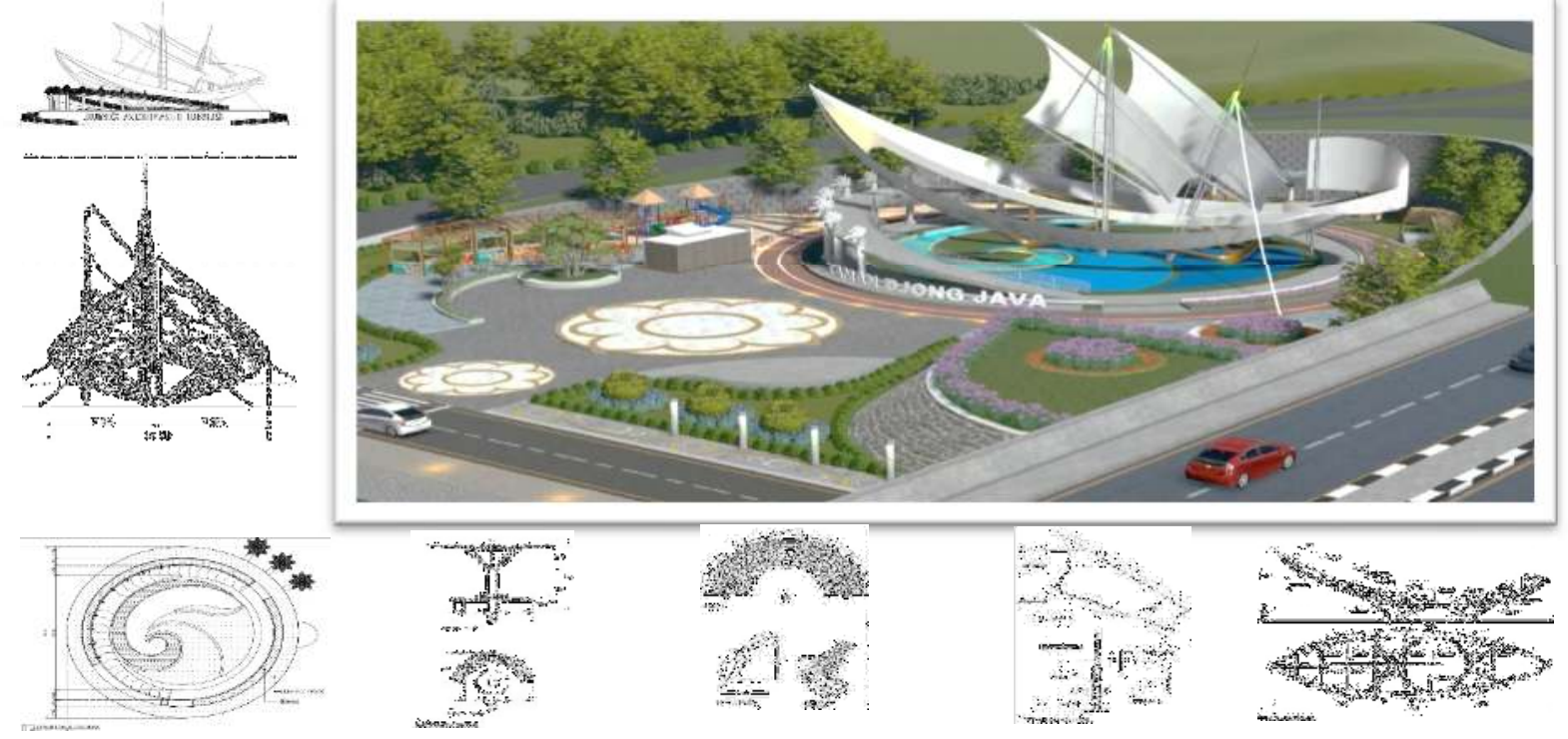

Gambar 5. Elemen Perancangan Taman

Organisasi ruang pada taman utama meliputi main entrance / pintu masuk utama yang diwujudkan dengan tangga berundak, menghantarkan pengunjung dari jalur pedestrian masuk ke lokasi taman. Main entrance diapit oleh vegetasi semak rendah sebagai pagar pembatas lokasi, sekaligus ornamen visual taman. Pada sisi tengah diletakkan ornamen lantai berbahan pattern concrete berupa lukisan bunga mawar. Disebelah kiri merupakan arena jajanan makanan (food court) dan taman bermain anak (play ground), sedangkan pada sisi kanan merupakan jalur bagi pejalan kaki untuk berolah raga dengan mengelilingi landmark (jogging track).

Landmark taman mengadopsi armada nelayan berupa kapal Djong Java. Kapal ini memiliki sejarah yang panjang di nusantara. Dimulai pada abad ke 15, kapal Djong Java mendominasi kapal kapal di Asia Tenggara. Kapal ini memiliki ukuran besar dengan bobot mencapai 350 hingga 500 ton muatan dengan beberapa ratus orang penumpang. Dengan ukuran tersebut, kapal Djong Java digunakan untuk perjalanan jarak jauh hingga lintas benua. Konstruksi kapal dibuat dari konstruksi dasar jalinan papan yang disatukan dengan kayu pasak, sehingga kuat menghadapi hantaman ombak dan oksidasi air laut.

Bentuk lantai dasar landmark berupa kolam air yang mencirikan air di lautan. Elemen air ini dapat perkembangannya dapat diganti dengan perkerasan berwarna biru laut jika dirasa menyulitkan dalam perawatannya. Pengunjung dalam menikmati taman dapat melakukan pendakian pada jalur ram yang mengelilingi kapal. Tempat ini merupakan spot foto yang potensial untuk mendapatkan vista pada landmark. Dengan jalur ini, maka 
pengunjung memiliki elevasi yang sama dengan kapal, sehingga mendapatkan nuansa mengarungi samudra dalam kapal Djong Java.

Perancangan ornamen pada lambung dan layar kapal dapat berupa batik khas Demak, diantaranya corak motif masjid agung, buah buahan, ikan dan lain sebagainya. Adapun bahan dasarnya menggunakan alumunium compocite panel (ACP).

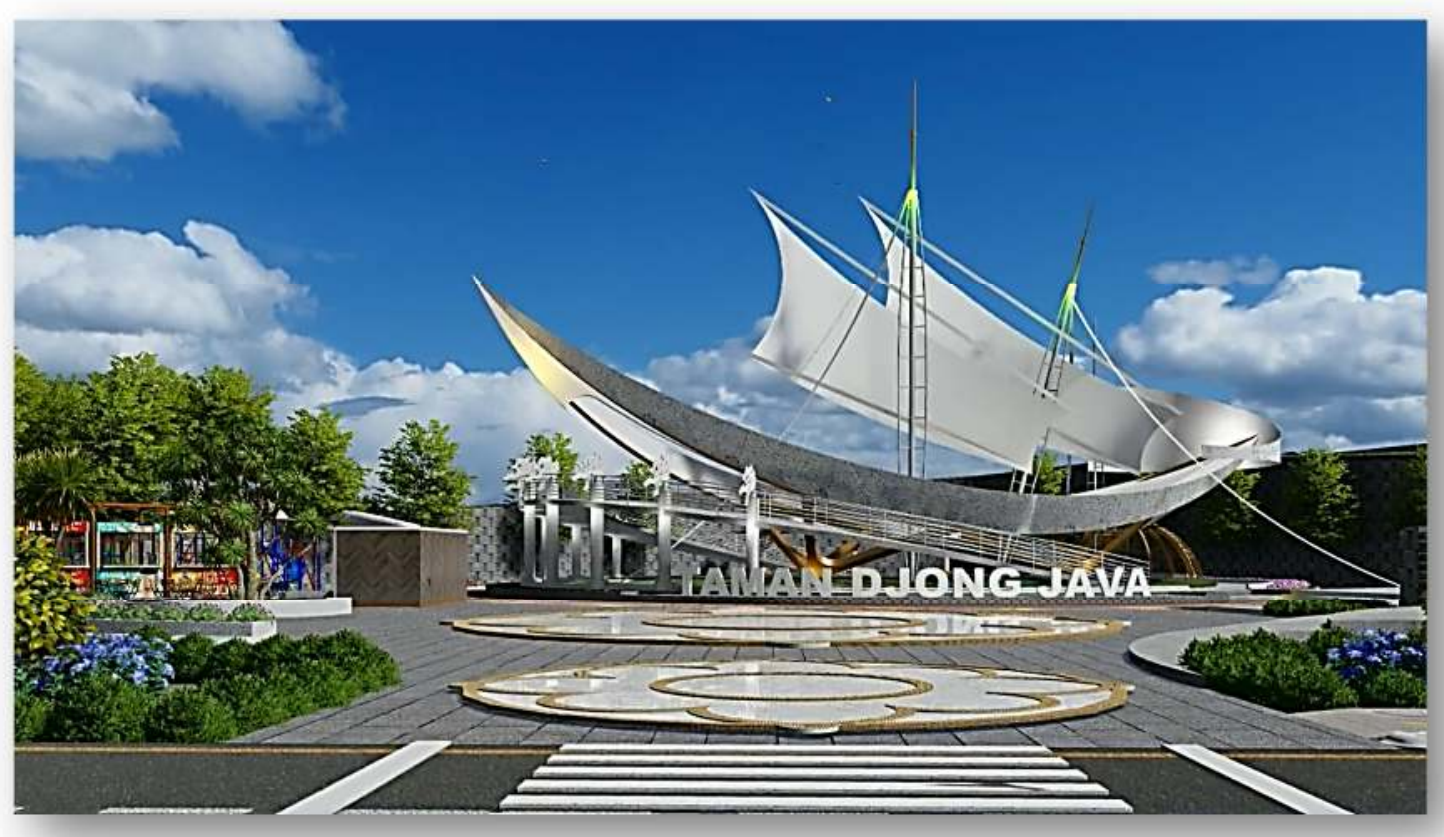

Gambar 6. Landmark Taman Diong Java

\section{KESIMPULAN}

Perancangan indentitas visual yang dikembangkan berdasarkan nilai nilai religi dan budaya pesisir diwujudkan dalam bentuk desain taman fly over Botorejo. Komposisi landmark berupa kapal Djong Jawa yang dihiasi dengan berbagai corak religi dan budaya tradisional menjadikan daya tarik yang khas. Melalui perancangan ini maka dapat diwujudkan identitas visual yang memiliki nilai memori kuat bagi para pengunjung baik lokal maupun manca. Hasil perancangan ini diharapkan dapat menjadi tetenger bagi identitas kota serta membentuk citra diri bagi sistem penanda kota di masa yang akan datang. 
Jurnal Planologi Vol. 18 No. 1, April 2021

Available: http://jurnal.unissula.ac.id/index.php/psa

\section{DAFTAR PUSTAKA}

Belia, A., \& Solikhah, E. (2010). Analisa Alun Alun Kota Tegal. Diploma in Architecture Design. Undip

Broadbent, G. (1973). Design in architecture: architecture and the human sciences. New York: John Wiley \& Sons.

Lawson, B. (1980). Design in Architecture - Architecture and the Human-Sciences Broadbent,G. Ergonomics.

Lynch Kevin (1969). Image at the City. MIT Press. Cambridge

Marwoto. Wulandari, E. (2014). Identitas Struktur Ruang Kota Demak. Seminar Nasional Eco City: Utopis atau Realis.

Salamah, U.-, \& Yananda, M. R. (2019). Constructing A Smart City Brand Identity: The Case of South Tangerang. Jurnal Komunikasi Indonesia.

Siraphatthada, Y., \& Thitivesa, D. (2020). Knowledge Intensive Herbal City Community Innovative Services in Thailand: Role of Solutions Provision Competence. Research in World Economy. https://doi.org/10.5430/rwe.v11n6p324

Zahn. Markus (2004). Perancangan kota Terpadu. Kanisius procceding. Ist International seminar National Symposium. Exebition and wordship in Urban design. 